\title{
The Effects of Anti-Dumping Duties in a Fixed Exchange Rate Regime
}

\author{
Chung-Fu Lai ${ }^{1}$ \\ ${ }^{1}$ Department of Applied Economics, Fo Guang University, Yilan County, Taiwan \\ Correspondence: Chung-Fu Lai, Associate Professor, Department of Applied Economics, Fo Guang University, No.160, \\ Linwei Rd., Jiaosi, Yilan County 26247, Taiwan.
}

Received: March 2, 2016

Accepted: March 14, 2016

Available online: March 22, 2016

doi:10.11114/aef.v3i3.1479

URL: http://dx.doi.org/10.11114/aef.v3i3.1479

\begin{abstract}
Absract
In this paper, New Open Economy Macroeconomics with micro-foundation was served as an analytical framework to explore long-term effect of domestic antidumping tax on macroeconomic variables (e.g. consumption, output, the price, and terms of trade) in a fixed exchange rate regime while the dumping by the foreign country into the home country. With theoretical derivation and simulation analysis, we found that when the ratio of export product price selling below its domestic retail price is lower, the antidumping tax is in positive relationship with the domestic consumption, foreign consumption, world consumption, domestic and foreign price indices, while is in negative relationship with domestic output, foreign output, and terms of trade. Besides, the larger ratio of export product price selling below its domestic retail price, the larger the degree of each macroeconomic variable fluctuates.
\end{abstract}

Keywords: anti-dumping duties, fixed exchange rate regime, new open economy macroeconomics

\section{Introduction}

With the increasing speed of globalization, companies should now compete with rivals from all over the world in order to gain a larger market share (Amiri Aghdaie et al., 2012; Riasi and Amiri Aghdaie, 2012). Although globalization can help to improve supply chains (Riasi, 2015a), financing channels (Riasi, 2015b), and marketing strategies (Ansari and Riasi, 2016; Riasi and Pourmiri, 2015, 2016), it might cause various damages to the economy as well. One of the possible damages of globalization is the threat of dumping and predatory pricing.

In order to maintain fair trade and make the development of domestic industries stable, levy of antidumping duty is an important tool that the government uses on an unfair trade with sales by lower than normal prices, however, the method of identifying damages caused by antidumping cases to industries has not yet specified by WTO, hence, it often raises controversy. And, exchange rate represents the relative price of domestic and foreign currency assets, which bears an important task of connecting domestic and foreign economy, modulating balance of internal and external economy, however, but, if a country adopts a fixed exchange rate regime, and the exchange rate cannot take initiatives on transmission function in the economic system, then, the topic of how far the impact of antidumping policy affects the macroeconomic variables is lack of full discussion. Furthermore, consumption home bias is a common phenomenon in the real world, showing a regular tendency of consumers having to prefer domestic commodities, hence, this paper intends to integrate consumption home bias into the effect of antidumping policy to analyze the macroeconomic effect of antidumping policy under a fixed exchange rate regime, and describes the role of consumption home bias.

The initial development of open economy analysis is mainly presented in Mundell-Fleming model (Mundell, 1963; Fleming, 1962) and Dornbusch (1976)'s model of Keynes doctrine as the base of theory, although these early model of open economy revealed and explained the relationship between some of the major macroeconomic variables, there is a common defect, namely, lack of micro-foundation. Lucas (1976) suggested that the changes in the macroeconomic variables may affect the decision of individuals, resulting in the change of the relationship among macroeconomic variables, so the shortage of micro-foundation analysis on macro economy will produce a bias. So, the birth of New Open Economy Macroeconomics (hereinafter referred to as NOEM) further opened a new phase to open development of macroeconomics, NOEM is a new generation of method to open economy research proposed by Obstfeld and Rogoff (1995), which is characterized by both micro-foundation and monopolistic competition market structure, very suitable for analyzing the impact of exogenous shocks in the macro economy, therefore, this paper used NOEM as the basis for analysis. 
Related literature on studies in topic of the economic effects of antidumping measures can be broadly grouped into three types as described below: The first category is the "empirical analysis on the effect of antidumping duties on the upstream/downstream industry", and related researches include that Webb (1992) suggested that the levy of antidumping duties would result in reduction of the quantity that an importing country imports, rise of production and profit, which helps domestic upstream industry of the importing country and may protect domestic industry, however, it is not necessarily favorable to the economic benefit of some downstream industry and consumers. Kelly and Morkre (1998) found that how do these domestic manufacturers in the importing country respond to the imported number of foreign product is related with the size of elasticity of substitution between domestic and foreign goods. The second category is "the analysis of effect of antidumping duties on the welfare", which including the research made by Prusa (1996) who used regression analysis method to identify null effect of lower antidumping tax on import after levying antidumping duty, wherein higher antidumping duties have significant and negative impact on import. Prusa (1999) found that antidumping duties have extremely large influence on import that reduced imported quantity and rise of imported price. Staiger and Wolak (1994) found that the effect of United States' antidumping policy on the transaction; when investigating the effect of levying antidumping tax, termination and deactivation, it will affect or restrict trade; Anderson et al. (1995) found that, if trades exist barriers, the antidumping policy will raise the social welfare of the importing country. The last category is "the analysis on the effect of antidumping duties on international trade", wherein related research including ones by Feinberg and Kaplan (1993), where they suggested that the antidumping may form a protection on industry, and the findings indicated that even if antidumping portion is determined negatively, once a complaint is filed, it will inhibit import. Krupp and Pollard (1996) discussed that the result of judging antidumping cases during each period of investigation has effect on the imported quantity of non-involved country. Prusa (1999) had study showing that industrialized countries often use antidumping regime to protect their industry, and developing countries also actively follow up; the impact of antidumping duties on import has been very large, where the imported quantity may drop down by about $70 \%$ and the imported prices may rise by $30 \%$ in taxed cases; in the antidumping cases with negative results, the imported quantity may drop down by $20 \%$ only by manipulating on trade survey. Prusa (2001) and Durling and Prusa (2006) have found that antidumping duties would reduce the quantity that manufacturers export to the suing countries significantly, namely, the effect of antidumping means damages trade a lot.

In summary, those literatures with analysis of the effect of antidumping duty, generally, focused on whether the levy of antidumping tax has adverse effects on upstream/downstream industry, welfare effects, as well as the effect of international trade, rare on discussion of the effect on open economy. Hence, this paper intends to expand NOEM model proposed by Obstfeld and Rogoff (1995) to discuss effect of antidumping duties in the macro economy. The reason why NOEM literature may be able to rise rapidly in the near future is mainly because that the theory architecture is analyzed based on imperfectly competitive market structure, and it has clear micro-foundation, hence, it was fond of by a considerable number of scholars, who reviewed a variety of issues from NOEM viewpoint, and the research on the effect of trade policies (such as the tariff policy) is one of NOEM topics.

Fender and Yip (2000) has discussed the effect of protection policy (tariffs) on domestic (foreign) output and welfare according to NOEM model proposed by Obstfeld and Rogoff (1995). Their study found that in the short-term, an increase in temporary tariff will result in decrease of domestic output, and its effect of affecting foreign output is uncertain; the effect of tariff policy in the long-term is the same as the conclusion made for that in the short-term. On the other hand, for the welfare, the raising tariffs will improve their welfare level, but the impact on foreign welfare is negative, and produces an effect of "beggar-thy-neighbor". However, this paper aroused more attention that although antidumping policy has become a very important trade policy tool of countries in the world, its role in an open economy still has not clearly been explained in the literature, we thus attempt to take NOEM proposed by Obstfeld and Rogoff (1995) as a theoretical framework to explore a long-term effect of home implementation of antidumping tax on the macroeconomic variables including consumption, output, price and terms of trade when a country adopted a fixed exchange rate regime and a foreign country imposed dumping measures on home country.

This paper will discuss it in four sections, except for the section of introduction, other sections are arranged as follows: Section 2 constructs a theoretical model, Section 3 makes simulation analysis to discuss the long-term effects of antidumping duty on macroeconomic variables, and Section 4 includes conclusions and suggestion.

\section{Theoretical Model}

\subsection{Model Setting}

This paper follows NOEM model proposed by Obstfeld and Rogoff (1995) as a theoretical basis, the main assumptions are as follows:

1) There are two countries in the world, "home country" and "foreign country", all of the following foreign economic variables are marked as "*” for identification. 
2) World population is distributed in the interval $[0,1]$, where individuals of home country is distributed between $[0$, $n)$ and foreign individuals are distributed between $[n, 1]$.

3) Each individual is both consumer and producer, and he operates a monopoly competitor factory and uses labor for production.

4) Dumping behavior exists in economic system.

5) Fixed exchange rate regime is implemented domestically.

\subsubsection{Household}

Assuming that all individuals have the same preferences, utility $(U)$ and consumption $(C)$ and real money balances $(M / P)$ are in positive proportional, and is inversely proportional to the output $(y)$, the lifetime utility function is set as follows:

$$
U_{t}=\sum_{s=t}^{\infty} \beta^{s-t}\left[\log C_{s}+\frac{\chi}{1-\varepsilon}\left(\frac{M_{s}}{P_{s}}\right)^{1-\varepsilon}-\frac{\kappa}{2} y_{s}(z)^{2}\right], \varepsilon>0
$$

Where $\beta$ is the discount factor $(0<\beta<1), \varepsilon$ is the elasticity of marginal utility of real money demand, $\chi$ and $\kappa$ represent the degree of significance of real money balances and output on the utility function, $z$ refers to a particular product.

In Eq. (1), define the consumption index of representative consumer as the function of constant elasticity of substitution (CES):

$$
C_{t}=\left[\int_{0}^{n} c_{h, t}(z)^{\frac{\delta-1}{\delta}} d z+\int_{n}^{1} c_{f, t}(z)^{\frac{\delta-1}{\delta}} d z\right]^{\frac{\delta}{\delta-1}}, \delta>1
$$

Where $c_{h}(z)$ is the consumption of domestic consumer for domestic specific products $z, c_{f}(z)$ is the consumption of domestic consumer for foreign specific product $z, \alpha$ is the consumption home bias parameters to measure the degree of domestic consumers preferring domestic goods, and $\delta$ is the elasticity of substitution of goods between countries.

Based on the definition of Eq. (2), it can be inferred that the domestic price index $(P)$ as shown in the following equation:

$$
P_{t}=\left[\int_{0}^{n} p_{h, t}(z)^{1-\delta} d z+\int_{n}^{1}(1+\tau)(1-\lambda) p_{f, t}(z)^{1-\delta} d z\right]^{\frac{1}{1-\delta}}, \quad \tau \leq \lambda
$$

Likewise, the foreign price index $\left(P^{*}\right)$ is as follows

$$
P_{t}^{*}=\left[\int_{0}^{n}\left(1+\tau^{*}\right)(1-\lambda) p_{h, t}^{*}(z)^{1-\delta} d z+\int_{n}^{1} p_{f, t}^{*}(z)^{1-\delta} d z\right]^{\frac{1}{1-\delta}}, \quad \tau^{*} \leq \lambda
$$

In the above two equations, $p_{h}(z)$ represents the price expressed with domestic currency for domestic goods $z$, $p_{f}(z)$ represents domestic currency price for foreign goods $z, p_{h}^{*}(z)$ represents that the foreign currency price for domestic goods $z, p_{f}^{*}(z)$ represents the foreign currency price for foreign goods $z$. In addition, because dumping behavior exists in the economic system, assuming that the proportion where the exported prices of both countries are lower than those domestically is $\lambda$, and both countries levy antidumping tax against the dumping behavior of the opponent country at the same time, the domestic and foreign antidumping taxes are $\tau$ and $\tau$ respectively. Although the levy of antidumping tax is a significant tool used by the government against unfair trading behavior to maintain stable development of domestic industries, however, as a general principle, antidumping tax may not exceed the margin of dumping, which is $\tau \leq \lambda$.

For any product, the law of one price is stated as follows:

$$
p_{h, t}(z)=E_{t} p_{h, t}^{*}(z)
$$




$$
p_{f, t}(z)=E_{t} p_{f, t}^{*}(z)
$$

Where $E$ represents the exchange rate.

From Eqs. (2) and (3), we can respectively derive consumption of domestic representative consumer on domestic and foreign specific commodity as follows:

$$
\begin{gathered}
c_{h, t}(z)=\left(\frac{p_{h, t}(z)}{P_{t}}\right)^{-\delta} C \\
c_{f, t}(z)=\left(\frac{(1+\tau)(1-\lambda) p_{f, t}(z)}{P_{t}}\right)^{-\delta} C
\end{gathered}
$$

Similarly, the consumption that foreign representative consumer on domestic and foreign specific commodity as follows:

$$
\begin{gathered}
c_{h, t}^{*}(z)=\left(\frac{\left(1+\tau^{*}\right)(1-\lambda) p_{h, t}^{*}(z)}{P_{t}^{*}}\right)^{-\delta} C^{*} \\
c_{f, t}^{*}(z)=\left(\frac{p_{f, t}^{*}(z)}{P_{t}^{*}}\right)^{-\delta} C^{*}
\end{gathered}
$$

In both equations as above, $c_{h}^{*}(z)$ represents the consumption that foreign consumers for domestic specific product, while $c_{f}^{*}(z)$ represents the consumption that foreign consumers for foreign specific product.

\subsubsection{Government}

In order to focus on the effect of antidumping tax, assuming that government sector did not generate expenditure, and return seigniorage and tariffs revenues in lump-sum fashion to the agent, then, the government budget constraint is:

$$
\frac{M_{t}-M_{t-1}}{P_{t}}+\frac{\tau(1-n) p_{f, t}(z)}{P_{t}}=T_{t}
$$

Where the $1^{\text {st }}$ item at the left hand side of the equation is real seigniorage, while the $2^{\text {nd }}$ item is real tariff revenues, and the right item of equation is the real transfer payments.

\subsubsection{Asset Market}

Suppose that international capital market is integrated and each individual can trade real bonds $(B)$ in the international capital market, the relationship between real interest rate $(r)$ and nominal interest rate $(i)$ of maturing bonds is as shown in Fisher equation, namely:

$$
1+i_{t}=\frac{P_{t+1}}{P_{t}}\left(1+r_{t}\right)
$$

Holding bonds reflects the lending relationship between the residents of two countries, thus satisfying $n B_{t}+(1-n) B_{t}^{*}=0$, or

$$
B_{t}^{*}=-\frac{n}{1-n} B_{t}
$$

Where $B_{t}$ refers to the amount of bonds held by domestic representative individual, $B_{t}^{*}$ refers to that held by foreign representative individual.

\subsubsection{Budget Constraint}

Budget constraint of representative individual is as follows:

$$
M_{t}+P_{t} C_{t}+P_{t} B_{t}=M_{t-1}+P_{t}\left(1+r_{t-1}\right) B_{t-1}+p_{h, t}(z) y_{h, t}(z)+P_{t} T_{t}
$$


In the equation, consumer's source of income in period $t$ includes: the balance of the money in period $t-1\left(M_{t-1}\right)$, the sum of principal and interest of bonds $\left(P_{t}\left(1+r_{t-1}\right) B_{t-1}\right)$, output revenue $\left(p_{h, t}(z) y_{h, t}(z)\right)$, and government transfer income $\left(P_{t} T_{t}\right)$, consumers can use the revenue of period $t$ to money holdings $\left(M_{t}\right)$, consumption $\left(P_{t} C_{t}\right)$, and bonds purchase $\left(P_{t} B_{t}\right)$.

\subsubsection{Aggregate Demand}

We can acquire domestic demand function faced by domestic manufacturer from Eqs. (7) and (9):

$$
y_{h, t}(z)=n c_{h, t}(z)+(1-n) c_{h, t}^{*}(z)=n\left(\frac{p_{h, t}(z)}{P_{t}}\right)^{-\delta} C+(1-n)\left(\frac{\left(1+\tau^{*}\right)(1-\lambda) p_{h, t}^{*}(z)}{P_{t}^{*}}\right)^{-\delta} C^{*}
$$

Likewise, based on Eqs. (8) and (10), it can be inferred that the demand function faced by the foreign manufacturer is:

$$
y_{f, t}^{*}(z)=n c_{f, t}(z)+(1-n) c_{f, t}^{*}(z)=n\left(\frac{(1+\tau)(1-\lambda) p_{f, t}(z)}{P_{t}}\right)^{-\delta} C+(1-n)\left(\frac{p_{f, t}^{*}(z)}{P_{t}^{*}}\right)^{-\delta} C^{*}
$$

\subsubsection{First Order Conditions}

When consumers are under the limitation of budget constraint (Eq. (14)), the first-order conditions for the maximization of the utility (Eq. (1)) are:

$$
\begin{gathered}
C_{t+1}=\beta\left(1+r_{t}\right) C_{t} \\
\frac{M_{t}}{P_{t}}=\left(\frac{\left(1+i_{t}\right) \chi}{i_{t}} C_{t}\right)^{\frac{1}{\varepsilon}} \\
{\left[y_{t}(z)\right]^{\frac{\delta+1}{\delta}}=\left(\frac{\delta-1}{k \delta}\right) C_{t}^{-1}\left(C_{t}^{W}\right)^{\frac{1}{\delta}}}
\end{gathered}
$$

Where Eq. (17) is Euler Equation of consumption, which describes intertemporal consumption behavior, Eq.(18) is an equation of money demand for indicating the substitution relationship between real money demand and consumption, Eq. (19) refers to the labor supply equation, which gives the alternative relationship between labor supply and consumption, in Eq. (19), $C^{W}$ represents world consumption, that is, $C_{t}^{W} \equiv n C_{t}+(1-n) C_{t}^{*}$.

\subsection{Derivation of Steady-State}

The following section discusses the effect of antidumping tax on every macroeconomic variable. Firstly, given that the economic system does not exist antidumping behavior and antidumping tax as an initial state ( 0 steady state) and as a baseline, then to seek an equilibrium solution in the long-term of economy system. In the following symbols, the subscript " $t$ " represents the macroeconomic variables in the long-term steady state, and the subscript " 0 " represents the macroeconomic variable in the initial state. For example: $C_{t}$ and $C_{0}$ represent the consumption in long-term steady state and initial state respectively.

Long-term steady state describes that the entire economic system reaches to a convergent state upon going through the exogenous shock. In the long-term steady state, all variables are fixed, and $B_{t}=B_{t+1}=0$. Therefore, we apply budget constraint of government sector (Eq. (11)) into the budget constraint of private sector (Eq. (14)) to get:

$$
C_{t}=\frac{p_{h, t}(z) y_{h, t}(z)+\tau(1-n) p_{f, t}(z)}{P_{t}}
$$

Likewise, for foreign country, we then have:

$$
C_{t}^{*}=\frac{p_{f, t}^{*}(z) y_{f, t}^{*}(z)+\tau^{*} n p_{f, t}^{*}(z)}{P_{t}^{*}}
$$




\subsection{Log-linearization}

In order to obtain closed-form solution, this paper uses approach proposed by Uhlig (1995). Firstly, we put model in log-linearization, then, to assign values to the parameters of the model to perform simulation analysis. (Note 1) Below we will put all variables in the vicinity of the initial state into log-linearization to obtain the degree of each variable fluctuates. In this paper, the superscript " $\wedge$ " mean the variable carrying out log-linearization.

For example: If $\hat{X}_{t}$ is the result of the variable $X_{t}$, performing $\log$-linearization in the initial state $\left(X_{0}\right)$, then:

$$
\hat{X}_{t} \equiv \ln \frac{X_{t}}{X_{0}} \cong \frac{X_{t}-X_{0}}{X_{0}} \cong \frac{d X_{t}}{X_{0}}
$$

\subsubsection{Log-Linearized Versions of Price Index}

Substitute Eqs. (5) and (6) into Eqs. (3) and (4), respectively, and put into log-linearization and use the feature of exchange rate will not change in a fixed exchange rate regime $\left(\hat{E}_{t}=0\right)$, we have:

$$
\begin{gathered}
\hat{P}_{t}=n \hat{p}_{h, t}(z)+(1-n)(1-\lambda)\left(\hat{p}_{f, t}^{*}(z)+\hat{\tau}\right) \\
\hat{P}_{t}^{*}=n(1-\lambda)\left(\hat{p}_{h, t}(z)+\hat{\tau}^{*}\right)+(1-n) \hat{p}_{f, t}^{*}(z)
\end{gathered}
$$

Subtract Eq. (23) from Eq. (22) to obtain difference between fluctuations of price indices of two countries:

$$
\hat{P}_{t}-\hat{P}_{t}^{*}=n \lambda p_{h, t}(z)-(1-n) \lambda \hat{p}_{f, t}^{*}+(1-n)(1-\lambda) \hat{\tau}-n(1-\lambda) \hat{\tau}^{*}
$$

2.3.2 Log-Linearized Versions of the Law of One Price

To log-linearize Eqs. (5) and (6) under the fixed exchange rate regime ( $\hat{E}_{t}=0$ ), we can obtain:

$$
\begin{aligned}
& \hat{p}_{h, t}(z)=\hat{p}_{h, t}^{*}(z) \\
& \hat{p}_{f, t}(z)=\hat{p}_{f, t}^{*}(z)
\end{aligned}
$$

\subsubsection{Log-Linearized Versions of World Budget Constraint}

We can get the world budget constraints from Eqs. (20) and (21):

$$
C_{t}^{W}=n C_{t}+(1-n) C_{t}^{*}=n \frac{p_{h, t}(z) y_{h, t}(z)+\tau(1-n) p_{f, t}(z)}{P_{t}}+(1-n) \frac{p_{f, t}^{*}(z) y_{f, t}^{*}(z)+\tau^{*} n p_{f, t}^{*}(z)}{P_{t}}
$$

Log-linearize Eq. (27) and use Eqs. (25) and (26), the following can be obtained:

$$
\begin{gathered}
\hat{C}_{t}^{W}=n\left(\hat{p}_{h, t}(z)+\hat{y}_{h, t}(z)-\hat{P}_{t}+(1-n)\left(\hat{p}_{f, t}^{*}(z)-\hat{P}_{t}^{*}+\hat{\tau}\right)\right. \\
+(1-n)\left(\hat{p}_{f, t}^{*}(z)+\hat{y}_{f, t}^{*}(z)-\hat{P}_{t}^{*}+n\left(\hat{p}_{h, t}(z)-\hat{P}_{t}+\hat{\tau}^{*}\right)\right.
\end{gathered}
$$

\subsubsection{Log-Linearized Versions of Demand Function}

Put domestic and foreign demand functions (Eqs. (15) and (16)) into log-linearization to get:

$$
\begin{aligned}
& \hat{y}_{h, t}(z)=-\delta\left(n\left(\hat{p}_{h, t}-\hat{P}_{t}\right)+(1-n)(1-\lambda)\left(\hat{p}_{h, t}^{*}(z)-\hat{P}_{t}^{*}+\hat{\tau}^{*}\right)\right)+\hat{C}_{t}^{W} \\
& \hat{y}_{f, t}^{*}(z)=-\delta\left(n(1-\lambda)\left(\hat{p}_{f, t}(z)-\hat{P}_{t}\right)+(1-n)\left(\hat{p}_{f, t}^{*}(z)-\hat{P}_{t}^{*}+\hat{\tau}\right)\right)+\hat{C}_{t}^{W}
\end{aligned}
$$

2.3.5 Log-Linearized Versions of Labor Supply Function

Log-linearize domestic labor supply function (Eq. (19)) and the following can be obtained: 


$$
(1+\delta) \hat{y}_{h, t}(z)=-\delta \hat{C}_{t}+\hat{C}_{t}^{W}
$$

Likewise, for foreign country, we have:

$$
(1+\delta) \hat{y}_{f, t}^{*}(z)=-\delta \hat{C}_{t}^{*}+\hat{C}_{t}^{W}
$$

2.3.6 Log-Linearized Versions of Money Demand Function

Log-linearize domestic money demand function (Eq. (18)) and the following can be obtained:

$$
\hat{M}_{t}-\hat{P}_{t}=\frac{1}{\varepsilon} \hat{C}_{t}
$$

Similarly, for foreign country, we have:

$$
\hat{M}_{t}^{*}-\hat{P}_{t}^{*}=\frac{1}{\varepsilon} \hat{C}_{t}^{*}
$$

Subtract Eq. (34) from Eq. (33) and use Eq. (24) and the following equation can be obtained:

$$
\hat{M}_{t}-\hat{M}_{t}^{*}=\frac{1}{\varepsilon}\left(\hat{C}_{t}-\hat{C}_{t}^{*}\right)+n \lambda p_{h, t}(z)-(1-n) \lambda \hat{p}_{f, t}^{*}-(1-n)(1-\lambda) \hat{\tau}-n(1-\lambda) \hat{\tau}^{*}
$$

\subsubsection{Log-Linearized Versions of Terms of Trade}

Define the terms of trade (TOT) as the ratio of export price to import price of the commodity, namely:

$$
T O T=\frac{p_{h, t}(z)}{E_{t} p_{f, t}^{*}(z)}
$$

In the fixed exchange rate regime ( $\hat{E}_{t}=0$ ), put Eq. (36) into log-linearization to obtain:

$$
T \hat{O} T=\hat{p}_{h, t}(z)-\hat{p}_{f, t}^{*}(z)
$$

\subsection{Steady-State Solution}

Log-linearize Eqs (20) and (21) and the following equation can be obtained:

$$
\begin{array}{r}
\hat{C}_{t}=\hat{p}_{h, t}(z)+\hat{y}_{h, t}(z)-\hat{P}_{t}+(1-n)\left(\hat{p}_{f, t}^{*}(z)-\hat{P}_{t}^{*}+\hat{\tau}\right) \\
\hat{C}_{t}^{*}=\hat{p}_{f, t}^{*}(z)+\hat{y}_{f, t}^{*}(z)-\hat{P}_{t}^{*}+n\left(\hat{p}_{h, t}(z)-\hat{P}_{t}+\hat{\tau}^{*}\right)
\end{array}
$$

We will seek solution of a total of 12 simultaneous equations, including the price index after log-linearization (Eqs. (22) and (23)), law of one price after log-linearization (Eqs. (25) and (26)), the world consumption after log-linearization (Eq. (28)), domestic and foreign demand function after log-linearization (Eqs. (29) and (30)), domestic and foreign labor supply function after log-linearization (Eqs. (31) and (32)), domestic and foreign money demand function subtraction equation after log-linearization (Eq. (35)), the terms of trade after log-linearization (Eq. (36)) and domestic and foreign private budget constraints after log-linearization (Eqs. (37) and (38)) to get correlation equation among 12 endogenous and exogenous variables, the 12 endogenous includes: domestic consumption $\left(\hat{C}_{t}\right)$, foreign consumption $\left(\hat{C}_{t}^{*}\right)$, the world consumption $\left(\hat{C}_{t}^{W}\right)$, domestic output $\left(\hat{y}_{h, t}(z)\right)$, foreign output $\left(\hat{y}_{f_{s} t_{*}}^{*}(z)\right)$, domestic price of particular product domestically $\left(\hat{p}_{h, t}(z)\right)$, foreign price of particular product domestically $\left(\hat{p}_{h, t}(z)\right)$, foreign price of particular product in a foreign country $\left.\left(\hat{p}_{f, t}^{*}(z)\right)\right)$, domestic price of a specific product in the foreign country $\left(\hat{p}_{f, t}(z)\right)$, domestic price index $\left(\hat{P}_{t}\right)$, foreign price index $\left(\hat{P}_{t}^{*}\right)$ and the terms of trade $\left(T \hat{O} T_{t}\right)$.

\section{The Effects of Antidumping Duty on Macroeconomic Variables}

This section presents the results of simulation analysis to discuss the effect of antidumping tax shock on macroeconomic variables.

\subsection{Parameterisation}

In order to simplify the analysis in this paper, on NOEM basis, we set two economic systems with equivalent size as the subjects of analysis, so, on the selection of the parameter, we try our best to introduce empirical data on the United States and countries with similar scale (such as OECD nations, the European Union) to analyze the effects of 
antidumping duty shock between the United States and other countries with similar size. Firstly, we follow setting mode of Bergin et al. (2007) to set the elasticity of substitution of goods between countries $(\delta$ ) to 5, besides, we follow practices of related literature submitted by Mankiw and Summers (1986) and Schmidt (2006) and set the elasticity of marginal utility of real money balance $(\varepsilon)$ to 1 , then, with the result of judging antidumping case pertaining to solar products that China sold to the United States recently and announced by the US Department of Commerce, and was levied from 26.33 to 58.87 percent of antidumping tax as an example, this paper simulated the proportion where exported sold price is lower than the domestic sold price of the goods $(\lambda)$ and the cases of domestic antidumping tax rate of change $(\hat{\tau}), 25 \%$ and $60 \%$ of each case, as for other domestic (foreign) policy variables, such as domestic money supply ( $\hat{M})$, foreign money supply $\left(\hat{M}^{*}\right)$, foreign antidumping tax $\left(\hat{\tau}^{*}\right)$, since it does not the focus to discuss in this paper, we assume that the change rate is 0 , and the parameter (variable) settings are as shown in Table 1.

Table 1. Parameters (variables) selected values

\begin{tabular}{ccc}
\hline Symbol & Meaning & Value \\
\hline$n$ & Country Size & 0.5 \\
$\delta$ & Elasticity of Substitution for Cross-Border Products & 5 \\
$\varepsilon$ & Elasticity of Marginal Utility for Real Money Balances & 1 \\
$\lambda$ & Ratio of export product price selling below its retail price & $25 \% \cdot 60 \%$ \\
$\hat{\tau}$ & Rate of Antidumping Duty & $25 \% \cdot 60 \%$ \\
\hline
\end{tabular}

\subsection{Simulation Analysis}

In this section, parameters set in the preceding section were used in the simulation to discuss the effects of antidumping tax on macroeconomic variables including consumption, prices, output and the terms of trade, wherein, the simulation results are set out in Table 2.

Table 2. Long-term effect of domestic antidumping duty on macroeconomic variables

(a) Long-term effect of domestic antidumping duty on domestic consumption

\begin{tabular}{|c|c|c|c|}
\hline & \multicolumn{3}{|c|}{$\hat{C}_{t}$} \\
\hline & \multicolumn{3}{|c|}{$\hat{\tau}$} \\
\hline \multirow{3}{*}{$\lambda$} & & 0.25 & 0.6 \\
\hline & 0.25 & 0.932 & - \\
\hline & 0.6 & -0.352 & -0.845 \\
\hline
\end{tabular}

Note: Antidumping tax should not exceed the margin of dumping.

(b) Long-term effect of domestic antidumping duty on foreign consumption

\begin{tabular}{|c|c|c|c|}
\hline & \multicolumn{3}{|c|}{$\hat{C}_{t}^{*}$} \\
\hline & \multicolumn{3}{|c|}{$\hat{\tau}$} \\
\hline \multirow{3}{*}{$\lambda$} & & 0.25 & 0.6 \\
\hline & 0.25 & 1.023 & - \\
\hline & 0.6 & -0.579 & -0.465 \\
\hline
\end{tabular}

(c) Long-term effect of domestic antidumping duty on world consumption

\begin{tabular}{|c|c|c|c|}
\hline & \multicolumn{3}{|c|}{$\hat{C}_{t}^{W}$} \\
\hline & \multicolumn{3}{|c|}{$\hat{\tau}$} \\
\hline \multirow{3}{*}{$\lambda$} & & 0.25 & 0.6 \\
\hline & 0.25 & 0.978 & - \\
\hline & 0.6 & -0.465 & -1.117 \\
\hline
\end{tabular}

(d) Long-term effect of domestic antidumping duty on domestic output

$$
\frac{y_{h, t}(z)}{\hat{\tau}}
$$




\begin{tabular}{|c|c|c|c|}
\hline \multirow{3}{*}{$\lambda$} & & 0.25 & 0.6 \\
\hline & 0.25 & -0.614 & - \\
\hline & 0.6 & 0.216 & 0.518 \\
\hline
\end{tabular}

(e) Long-term effect of domestic antidumping duty on foreign output

\begin{tabular}{|c|c|c|c|}
\hline & \multicolumn{3}{|c|}{$y_{f, t}^{*}(z)$} \\
\hline & \multicolumn{3}{|c|}{$\hat{\tau}$} \\
\hline \multirow{3}{*}{$\lambda$} & & 0.25 & 0.6 \\
\hline & 0.25 & -0.690 & - \\
\hline & 0.6 & 0.405 & 0.971 \\
\hline
\end{tabular}

(f) Long-term effect of domestic antidumping duty on domestic price index

\begin{tabular}{|c|c|c|c|}
\hline & \multicolumn{3}{|c|}{$\hat{P}_{t}$} \\
\hline & \multicolumn{3}{|c|}{$\overline{\hat{\tau}}$} \\
\hline \multirow{3}{*}{$\lambda$} & & 0.25 & 0.6 \\
\hline & 0.25 & 7.699 & - \\
\hline & 0.6 & 1.060 & 2.543 \\
\hline
\end{tabular}

(g) Long-term effect of domestic antidumping duty on foreign price index

\begin{tabular}{|c|c|c|c|}
\hline & \multicolumn{3}{|c|}{$\hat{P}_{t}^{*}$} \\
\hline & \multicolumn{3}{|c|}{$\hat{\tau}$} \\
\hline \multirow{3}{*}{$\lambda$} & & 0.25 & 0.6 \\
\hline & 0.25 & 7.675 & - \\
\hline & 0.6 & -1.380 & -3.313 \\
\hline
\end{tabular}

(h) Long-term effect of domestic antidumping duty on the price of domestic product $z$ denoted in domestic currency

\begin{tabular}{|c|c|c|c|}
\hline \multicolumn{4}{|c|}{$\hat{p}_{h, t}(z)$} \\
\hline & \multicolumn{3}{|c|}{$\hat{\bar{\tau}}$} \\
\hline \multirow{3}{*}{$\lambda$} & & 0.25 & 0.6 \\
\hline & 0.25 & 8.452 & - \\
\hline & 0.6 & -1.328 & -3.188 \\
\hline
\end{tabular}

(i) Long-term effect of domestic antidumping duty on the price of domestic product $z$ denoted in foreign currency

\begin{tabular}{|c|c|c|c|}
\hline & \multicolumn{3}{|c|}{$\hat{p}_{h, t}^{*}(z)$} \\
\hline & \multicolumn{3}{|c|}{$\bar{\tau}$} \\
\hline \multirow{3}{*}{$\lambda$} & & 0.25 & 0.6 \\
\hline & 0.25 & 8.452 & - \\
\hline & 0.6 & -1.328 & -3.188 \\
\hline
\end{tabular}

(j) Long-term effect of domestic antidumping duty on the price of foreign product $z$ denoted in domestic currency 


\begin{tabular}{|c|c|c|c|}
\hline & \multicolumn{3}{|c|}{$\hat{p}_{f, t}(z)$} \\
\hline & \multicolumn{3}{|c|}{$\hat{\tau}$} \\
\hline \multirow{3}{*}{$\lambda$} & & 0.25 & 0.6 \\
\hline & 0.25 & 9.011 & - \\
\hline & 0.6 & -2.229 & -5.350 \\
\hline
\end{tabular}

(k) Long-term effect of domestic antidumping duty on the price of foreign product $z$ denoted in foreign currency

\begin{tabular}{|c|c|c|c|}
\hline & \multicolumn{3}{|c|}{$\hat{p}_{f, t}^{*}(z)$} \\
\hline & \multicolumn{3}{|c|}{$\hat{\tau}$} \\
\hline \multirow{3}{*}{$\lambda$} & & 0.25 & 0.6 \\
\hline & 0.25 & 9.011 & - \\
\hline & 0.6 & -2.229 & -5.350 \\
\hline
\end{tabular}

(1) Long-term effect of domestic antidumping duty on terms of trade

\begin{tabular}{|c|c|c|c|}
\hline \multicolumn{4}{|c|}{$T \hat{O} T_{t}$} \\
\hline \multicolumn{4}{|c|}{$\hat{\tau}$} \\
\hline \multirow{3}{*}{$\lambda$} & & 0.25 & 0.6 \\
\hline & 0.25 & -0.559 & - \\
\hline & 0.6 & 0.901 & 2.163 \\
\hline
\end{tabular}

Known by Table 2 (a) to (1), in the long-term, when the dumping margin is lower, the rise of antidumping tax will increase the level of domestic consumption, foreign consumption, world consumption, the domestic price index, foreign price index, domestic selling prices of domestic commodities, foreign selling prices of domestic commodities, domestic sold prices of foreign goods and foreign goods sold in foreign countries, but it will drop down the domestic output and foreign output, deteriorating terms of trade; when the dumping margin is higher, the effect of antidumping tax on each economic variable will change. Namely, when the dumping margin is higher, the rise of antidumping tax would drop down domestic consumption, domestic output rises and the terms of trade were improved, and when the margin of dumping and antidumping tax rate are at a high level at the same time, the rise of antidumping tax will drop down domestic price level.

The intuition on economy behind the foregoing conclusions can be explained as follows: In an open economy system with imperfectly competitor, since the government transfers antidumping tax to the agent, the rise of antidumping tax rate represents the situation that individual would get higher proportions of fixed-amount transfer, the consumption increases, and the increase of the level of consumption, on the one hand, drives the rise in prices, deteriorating terms of trade, and the higher margin of dumping and antidumping tax rate is, the more reverse the antidumping tax affects each macroeconomic variable.

\section{Conclusion and Suggestions}

According to the definition of "Antidumping Agreement" by WTO, when the export price of goods is lower than its domestic prices, it constitutes suspect of imposing "dumping" against the importing countries. When a particular commodity is dumped causing damages to the importing country's industries, and a causal relationship exists between dumping and damage, the importing country may apply for antidumping investigations on specific commodities in specific countries. Once confirmed by the importing country that its lower price indeed damaged the importing country's industry, it can levy "antidumping tax" against those imported goods dumped at low price. Taking into consideration that the antidumping policy has been one of the quite common trade policy tools, this paper takes the effect of antidumping tax on macro economy as an analytical topic, hoping to provide the reference as developments of performance improvement strategies and relevant government departments adopting trade remedy measures.

Up to now, NOEM has elapsed more than 20 years for development, however, compared to the popularity in the study 
of effect by monetary and fiscal shocks, those in topic of trade shock (such as antidumping tax) are rare; in view of the above reasons, this paper takes NOEM as a theory framework to discuss the effect of antidumping duty on macro economy. Via theoretical derivation and simulation analysis, we find that under a fixed exchange rate regime, when the proportions that the exported price being lower than domestic price is lower, the rise of antidumping tax will lead to rise of domestic consumption, foreign consumption, world consumption, domestic price index and foreign consumer price index, but will drop down domestic output, foreign output and the terms of trade, and with larger proportions where the exported price being lower than the domestic sales price of the goods, the scale of antidumping tax affecting each macroeconomic variables would also be more intense.

Finally, it shall be specially noted that, NOEM theoretical framework, although has played its significance among each economic issue, in fact, it usually needs to build under a number of hypothesis to seek solution easily. If we try to relax one of assumptions or settings (such as the form of utility function), the results obtained may differ and this deficiency will also be included in the restrictions suffered herein.

\section{References}

Amiri Aghdaie, S. F., Seidi, M., \& Riasi, A. (2012). Identifying the Barriers to Iran's Saffron Export by Using Porter's Diamond Model. International Journal of Marketing Studies, 4(5), 129-138. http://dx.doi.org/10.5539/ijms.v4n5p129

Anderson, S. P., Schmitt, N., \& Thisse, J. F. (1995). Who Benefits from Antidumping Legislation?. Journal of International Economics, 38(3-4), 321-337. http://dx.doi.org/10.1016/0022-1996(94)01347-U

Ansari, A., \& Riasi, A. (2016). An Investigation of Factors Affecting Brand Advertising Success and Effectiveness. International Business Research, 9(4), 1-11.

Bergin, P., Shin, H., \& Tchakarov, I. (2007). Does Exchange Rate Variability Matter for Welfare? A Quantitative Investigation of Stabilization Policies. European Economic Review, 51(4), 1041-1058. http://dx.doi.org/10.1016/j.euroecorev.2006.05.002

Dornbusch, R. (1976). Expectations and Exchange Rate Dynamics. Journal of Political Economy, 84, 1161-1176. http://dx.doi.org/10.1086/260506

Durling, J. P., \& Prusa, T. J. (2006). The Trade Effects Associated with an Antidumping Epidemic: The Hot-Rolled Steel Market, 1996-2001. European Journal of Political Economy, 22(3), 675-695. http://dx.doi.org/10.1016/j.ejpoleco.2005.08.006

Feinberg, R. M., \& Kaplan, S. (1993). Fishing Downstream: The Political Economy of Effective Administered Protection. Canadian Journal of Economics, 26(1), 150-158. http://dx.doi.org/10.2307/135850

Fender, J., \& Yip, K. C. (2000). Tariffs and Exchange Rate Dynamics Redux. Journal of International Money and Finance, 19, 633-655. http://dx.doi.org/10.1016/S0261-5606(00)00027-9

Fleming, J. M. (1962). Domestic Financial Policies Under Fixed and Under Floating Exchange Rates. IMF Staff Papers, 9(3), 369-379. http://dx.doi.org/10.2307/3866091

Kelly, K. M., \& Morkre, M. E. (1998). Do Unfairly Traded Imports Injure Domestic Industries?. Review of International Trade, 6(2), 321-332. http://dx.doi.org/10.1111/1467-9396.00106

Krupp, C. M., \& Pollard, P. S. (1996). Market Responses to Antidumping Laws: Some Evidence from U.S. Chemical Industry. Canadian Journal of Economics, 29(1), 199-227. http://dx.doi.org/10.2307/136159

Lucas, R. E. (1976). Econometric Policy Evaluation: A Critique. Carnegie-Rochester Conference Series on Public Policy, 1, 19-46. http://dx.doi.org/10.1016/S0167-2231(76)80003-6

Mankiw, N. G., \& Summers, L. H. (1986). Money Demand and the Effects of Fiscal Policies. Journal of Money, Credit and Banking, 18(4), 415-429. http://dx.doi.org/10.2307/1992462

Mundell, R. A. (1963). Capital Mobility and Stabilization Policy under Fixed and Flexible Exchange Rates. Canadian Journal of Economics and Political Science, 29(4), 475-485. http://dx.doi.org/10.2307/139336

Obstfeld, M., \& Rogoff, K. (1995). Exchange Rate Dynamics Redux. Journal of Political Economy, 103(3), 624-660. http://dx.doi.org/10.1086/261997

Prusa, T. J. (1996). The Trade Effects of U.S. Antidumping Actions. NBER Working Paper, 5440.

Prusa, T. J. (1999). On the Spread and Impact of Antidumping. NBER Working Paper, 7404.

Prusa T. J. (2001). On the Spread and Impact of Anti-Dumping. Canadian Journal of Economics, 34(3), $591-611$. 
Riasi, A. (2015a). Barriers to international supply chain management in Iranian flower industry. Management ScienceLetters, 5(4), 363-368. http://dx.doi.org/10.5267/j.msl.2015.2.005

Riasi, A. (2015b). Competitive Advantages of Shadow Banking Industry: An Analysis Using Porter Diamond Model. Business Management and Strategy, 6(2), 15-27. http://dx.doi.org/10.5296/bms.v6i2.8334

Riasi, A., \& Amiri Aghdaie, S. F. (2013). Effects of a Hypothetical Iranian Accession to the World Trade Organization on Iran's Flower Industry. Consilience: The Journal of Sustainable Development, 10(1), 99-110. http://dx.doi.org/10.7916/D8HQ3ZK8

Riasi, A., \& Pourmiri, S. (2015). Effects of online marketing on Iranian ecotourism industry: Economic, sociological, and cultural aspects. Management Science Letters, 5(10), 915-926. http://dx.doi.org/10.5267/j.ms1.2015.8.005

Riasi, A., \& Pourmiri, S. (2016). Examples of Unsustainable Tourism in Middle East. Environmental Management and Sustainable Development, 5(1), 69-85. http://dx.doi.org/10.5296/emsd.v5i1.8705

Schmidt, C. (2006). International Transmission Effects of Monetary Policy Shocks: Can Asymmetric Price Setting Explain the Stylized Facts?. International Journal of Finance and Economics, 11(3), 205-218. http://dx.doi.org/10.1002/ijfe.293

Staiger, R. W., \& Wolak, F. (1994). Measuring Industry Specific Protection: Antidumping in the United States. NBER Working Paper, No. W4696.

Uhlig, H. (1995). A Toolkit for Analyzing Nonlinear Dynamic Stochastic Models Easily. Center for Economic Research Discussion Paper, 97, Tilburg University.

Webb, M. (1992). The Ambiguous Consequences of Anti-dumping Laws. Economics Inquiry, $30(3), 437-448$. http://dx.doi.org/10.1111/j.1465-7295.1992.tb01973.x

\section{Notes}

Note 1. Because of the complexity of the model setting, in order to obtain a closed-form solution between exogenous variables and endogenous variables, two ways were more frequently used in the literature: log-linearization and numerical simulations. This paper is to use log-linearization incorporated with numerical simulation.

\section{$(\mathrm{cc}) \mathrm{Br}$}

This work is licensed under a Creative Commons Attribution 3.0 License. 